\title{
Design and evaluation of check basin irrigation system using SURDEV software model
}

\section{K. KISHAN, K. KRUPAVATHI AND H.V. HEMA KUMAR}

Received : 21.06.2016; Revised : 29.08.2016; Accepted : 14.09 .2016

See end of the Paper for authors' affiliation

Correspondence to :

\section{K. KRUPAVATHI}

College of Agricultural

Engineering, Bapatla, GUNTUR (A.P.) INDIA

Email : krupareddy572@gmail.

com
- ABSTRACT : For efficient and judicious use of water resources, an accurate design and high quality optimization of the check basin irrigation system is necessary. BASDEV of SURDEV model was used to evaluate the check basin irrigation system of size $30 \mathrm{~m} \times 45 \mathrm{~m}$ for medium soils in Bapatla, Guntur District, Andhra Pradesh, India, for an irrigation application depth of $75 \mathrm{~mm}$ with a stream size of 10, 20, 30, 40, 50, 60, 70, 80 and $90 \mathrm{lps}$. To optimize the efficiency of the design, the model was run varying the basin design dimensions and cutoff times. The outputs of BASDEV, is intended to improve the overall efficiency of basin irrigation system, provided optimum field dimensions for border irrigation in medium textured soils.

KEY WORDS : Application efficiency, BASDEV, Basin irrigation, Surface irrigation, Water Management, SURDEV

HOW TO CITE THIS PAPER : Kishan, K, Krupavathi, K. and Kumar, H.V. Hema (2016). Design and evaluation of check basin irrigation system using SURDEV software model. Internat. J. Agric. Engg., 9(2) : 188-195, DOI: 10.15740/HAS/IJAE/9.2/188-195. 